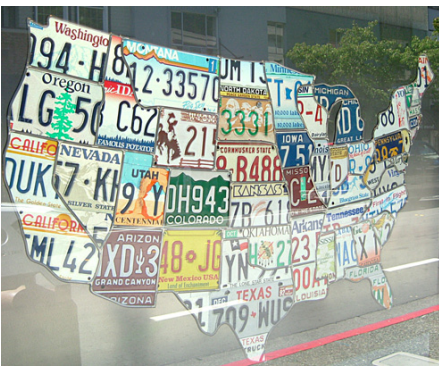

\section{Making the Case for Uniformity in Professional State Licensure Requirements}

\author{
Janice A. Brannon, Ellen R. Cohn, and Jana Cason \\ American Telemedicine Association's Special Interest Group on Telerehabilitation, \\ License Portability Sub-Committee (Co-chairs)
}

\begin{abstract}
Telehealth, the use of communication and information technologies to deliver health services, was initially envisioned as a way for persons in rural or remote settings to receive otherwise unavailable healthcare services. Now, in addition to overcoming personnel shortages for underserved populations, telehealth shows promise in meeting the needs of a constantly mobile U.S. society and workforce. Fortunately, telerehabilitation can meet the needs of a mobile society and workforce by enabling continuity of care for individuals who are out-of-town, on vacation, in temporary residence as a university student, or on business travel. Unfortunately, outdated legislative and regulatory policies and inhospitable infrastructures currently stand in the way of a seamless continuum of care.
\end{abstract}

In 2010, the American Telemedicine Association's Telerehabilitation Special Interest Group (TR SIG) convened a License Portability Sub-Committee to explore ways to diminish barriers for state licensure portability with a particular focus on physical therapy, occupational therapy, speech therapy, and audiology. In 2011, the Subcommittee published a factsheet (1) that detailed the challenges and potential solutions that surround the difficult issue of licensure portability. Concurrently, the American Telemedicine Association is advocating for national reform of professional licensure. (2)

At the heart of all licensure requirements is the ability to determine who should be granted the authority to practice in a particular profession. This is done by focusing on educational, examination and behavioral requirements that are deemed the minimum necessary to protect the public from harm. States, however, with whom authority for licensure of health professionals rests, have independently defined those minimum requirements. This approach has led to a myriad of requirements that vary from state to state.

Licensure portability will best succeed when variability between licensure requirements is minimized and an efficient licensure process exists. In this paper, these two critical factors for licensure portability are referred to as "licensure requirements" and "the credentialing process." Currently the variability between both of these factors is different between professions as well as between jurisdictions. To find the best solution to licensure portability, it is critical to determine which of these two elements create significant barriers for licensure mobility. This document outlines a method for the professions to begin collecting data to pinpoint the areas where agreement and variations exist in licensure requirements and processes between states. Such information will inform efforts towards uniformity.

\section{Introduction}

Telerehabilitation Defined

The American Telemedicine Association's Telerehabilitation SIG, a multi-disciplinary group comprised of speech-language pathologists, audiologists, occupational therapy practitioners, physical therapy practitioners, rehabilitation engineers, and other health professionals constructed an inclusive and far-reaching definition for telerehabilitation in their Blueprint for Telerehabilitation Guideline (4):

Telerehabilitation refers to the delivery of rehabilitation services via information and communication technologies. Clinically, this term encompasses a range of rehabilitation and habilitation services that include assessment, monitoring, prevention, intervention, supervision, education, consultation, and counseling. Telerehabilitation has the capacity to provide service across the lifespan and across a continuum of care. Just as the services and providers of telerehabilitation are broad, so are the points of service, which may include health care settings, clinics, homes, schools, or community-based worksites. (p. 31)

Inter-state Telerehabilitation for a Mobile Society In a mobile society, it is not uncommon for consumers of health care to travel between states for work, education and/or recreation. Further, ease of mobility has led many individuals to live in multiple locations whether by season, proximity to business, vacation or to be near family. Likewise, health care services and providers need to be portable and available regardless of geographic location. Indeed, with the advancements in technology and mobile devices, we are truly evolving into a boundless and continuously connected society.

\section{Licensure Barriers To Inter-State Practice}

Despite the realities of our mobile modern society and the ease with which technology can erase state lines, allied health professionals (e.g., audiologists, occupational therapy practitioners, physical therapy practitioners, speech-language pathologists, etc.) may only engage in telerehabilitation within states where they hold a professional license. This is akin to needing a different driver's license to drive in each US state and territory.

In 2001, the US Department of Health and Human Services, Health Resources and Services Administration (HRSA) (5) in its report to Congress, identified licensure as a major barrier to interstate practice; in 2007 the American Telemedicine Association came to similar conclusions (6). More recently, HRSA (3) has addressed the benefits of licensure portability:

"Overcoming unnecessary licensure barriers to cross-state practice is seen as a part of a general strategy to expedite the mobility of health professionals to address workforce needs and 
improve access to health care services, particularly in light of increasing shortages of healthcare professions. It is also seen as a way of improving the efficiency of the licensing system in this country so that scarce resources can be better used in the disciplinary and enforcement activities of state boards, rather than in duplicative licensing processes." (p. 5)

\section{Licensure Requirements}

In general, there are three core requirements that each professional must evidence to be considered for a license: education, examination and behavior requirements. However, this is where uniformity in requirements ends. States may have additional requirements such as jurisprudence exams, criminal background checks, or specific continuing education course requirements (e.g. prevention of medical errors, ethics), in addition to other state-based requirements.

Appendix A provides a template that can be used to gather and compare selected aspects of licensure requirements across all US states.

\section{The Credentialing Process}

Practitioners who must apply for additional state licenses report duplicative paperwork, expense, and long wait times. The extent of the wait times and expense varies between professions and between states. It is important to gain insight into the processes and causes of delays in order to resolve them. Inefficient technology as well as state budget limitations may exacerbate the problems. Thus, maintaining more than one state license can be expensive and time consuming.

Appendix B provides a template that can be used to gather and compare selected aspects of the credentialing process across all US states.

\section{Progressing Toward Uniformity}

Many state-based professional licensure systems contain jurisdictional variations that make it difficult to facilitate the mobility of licensed health professionals. If the areas of core requirements are uniform, tools such as a uniform licensure application and a central verification system could streamline an expedited licensure process. States are challenged to consider:

- Does customization of professional licensure requirement benefit clients/patients?

- What could be done to create efficiencies in the credentialing process?

Deconstructing the current, customized licensure system toward uniformity will undoubtedly be difficult. Moreover, it is not clear, from where the impetus for uniformity might come (e.g., federal, state, licensure bodies, and/or professional association based initiatives). On a positive note, there are opportunities to increase uniformity. Areas of agreement are discoverable for states' licensure requirements.

A proposed protocol to discern opportunities follows:

1. Determine if the laws are similar, state to state (profession specific) based on the following required credentials: identity, education, post-graduate training, examination, disciplinary history and continuing education.
2. Determine the time and cost of the credentialing process for a licensee on a state-by-state basis.

It is suggested that professional associations, regulatory bodies or certification agencies may utilize the answers to these questions and the accompanying tables (Appendices A \& B) to develop a pathway to agreement for licensure boards. Identifying areas of uniformity could inform changes in the core requirements and administrative processes for issuing licenses for the allied health professions.

\section{Conclusions and Acknowledgements}

The current state-based licensure and regulation of allied health professionals does not facilitate inter-state practice. Given today's technology and its utilization for many kinds of services; health care providers, including allied health professionals, should be able to serve clients/patients wherever they are needed. Movement towards uniformity may enhance access to health services, increase efficiencies in the licensure process, reduce administrative costs, and facilitate licensure portability.

This document was authored by a sub-committee of the American Telemedicine Association's Telerehabilitation Special Interest Group (SIG), and incorporated the generous input of members of an interdisciplinary working group (IWG). It does not represent an official document of any professional association, federation or association of state licensing boards. For further information, please contact: Ellen Cohn, (ecohn@pitt.edu). Graphic support was supplied by the RERC on Telerehabilitation funded by NIDRR Department of Education, Washington DC, Grant \# H133E090002.

\section{References}

1. Cohn, E.R., Brannon, J.A., Cason, J. (2011). Resolving barriers to licensure portability fortelerehabilitation professionals: American Telemedicine Association's Telerehabilitation Special Interest Group, Licensure Working Portability Working Group report. International Journal of Telerehabilitation, 3(2), 31-34. doi: 10.5195/ijt.2011.6078

2. American Telemedicine Association. (2011). Medical licensure and practice requirements. Retrieved from http:// www.americantelemed.org/files/public/policy/ATAPolicy_ StateMedicalLicensure.pdf

3. U.S. Department of Health and Human Services, Health Resources and Services Administration. (2010). Health Licensing Board, Report to Congress, Senate Report 11166. Retrieved from http://www.hrsa.gov/ruralhealth/about/ telehealth/licenserpt10.pdf

4. Brennan, D., Tindall, L., Theodoros, D., Brown, J., Campbell, M., Christiana, D., Smith, D., Cason, J., \& Lee, A. (2010). A blueprint for telerehabilitation guidelines. International Journal of Telerehabilitation, 2, 31-34. doi: 10.5195/ijt.2010.6063

5. U.S. Department of Health and Human Services, Health Resources and Services Administration. (2001). 2001 Telemedicine report to Congress. Retrieved from ftp://ftp.hrsa. gov/telehealth/report2001.pdf

6. American Telemedicine Association. (2007). Licensure portability position statement and recommendations. Retrieved from http://media.americantelemed.org/news/Whitepapers/ Medical\%20Licensure\%20Portability\%20Position.pdf 
APPENDIX A:

\section{LICENSURE REQUIREMENTS: US STATES}

\begin{tabular}{|c|c|c|c|c|c|c|c|}
\hline State & $\begin{array}{l}\text { Education/ } \\
\text { Degree }\end{array}$ & $\begin{array}{l}\text { Clinical } \\
\text { Training }\end{array}$ & $\begin{array}{l}\text { National } \\
\text { Exam (s) }\end{array}$ & $\begin{array}{l}\text { Jurisdictional } \\
\text { Exam(s) }\end{array}$ & $\begin{array}{l}\text { Criminal } \\
\text { Checks }\end{array}$ & $\begin{array}{l}\text { Prior } \\
\text { Disciplinary } \\
\text { Infraction }\end{array}$ & $\begin{array}{l}\text { Post Graduate } \\
\text { Continuing Ed } \\
\text { Requirements }\end{array}$ \\
\hline \multicolumn{8}{|l|}{ Alabama } \\
\hline \multicolumn{8}{|l|}{ Alaska } \\
\hline \multicolumn{8}{|l|}{ Arizona } \\
\hline \multicolumn{8}{|l|}{ Arkansas } \\
\hline \multicolumn{8}{|l|}{ California } \\
\hline \multicolumn{8}{|l|}{ Colorado } \\
\hline \multicolumn{8}{|l|}{ Connecticut } \\
\hline \multicolumn{8}{|l|}{ Delaware } \\
\hline \multicolumn{8}{|l|}{$\begin{array}{l}\text { District of } \\
\text { Columbia }\end{array}$} \\
\hline \multicolumn{8}{|l|}{ Florida } \\
\hline \multicolumn{8}{|l|}{ Georgia } \\
\hline \multicolumn{8}{|l|}{ Hawaii } \\
\hline \multicolumn{8}{|l|}{ Idaho } \\
\hline \multicolumn{8}{|l|}{ Illinois } \\
\hline \multicolumn{8}{|l|}{ Indiana } \\
\hline \multicolumn{8}{|l|}{ lowa } \\
\hline \multicolumn{8}{|l|}{ Kansas } \\
\hline \multicolumn{8}{|l|}{ Kentucky } \\
\hline \multicolumn{8}{|l|}{ Louisiana } \\
\hline \multicolumn{8}{|l|}{ Maine } \\
\hline \multicolumn{8}{|l|}{ Maryland } \\
\hline \multicolumn{8}{|l|}{ Massachusetts } \\
\hline \multicolumn{8}{|l|}{ Michigan } \\
\hline \multicolumn{8}{|l|}{ Minnesota } \\
\hline \multicolumn{8}{|l|}{ Mississippi } \\
\hline \multicolumn{8}{|l|}{ Missouri } \\
\hline \multicolumn{8}{|l|}{ Montana } \\
\hline Nebraska & & & & & & & \\
\hline Nevada & & & & & & & \\
\hline $\begin{array}{l}\text { New } \\
\text { Hampshire }\end{array}$ & & & & & & & \\
\hline New Jersey & & & & & & & \\
\hline New Mexico & & & & & & & \\
\hline New York & & & & & & & \\
\hline North Carolina & & & & & & & \\
\hline North Dakota & & & & & & & \\
\hline Ohio & & & & & & & \\
\hline
\end{tabular}




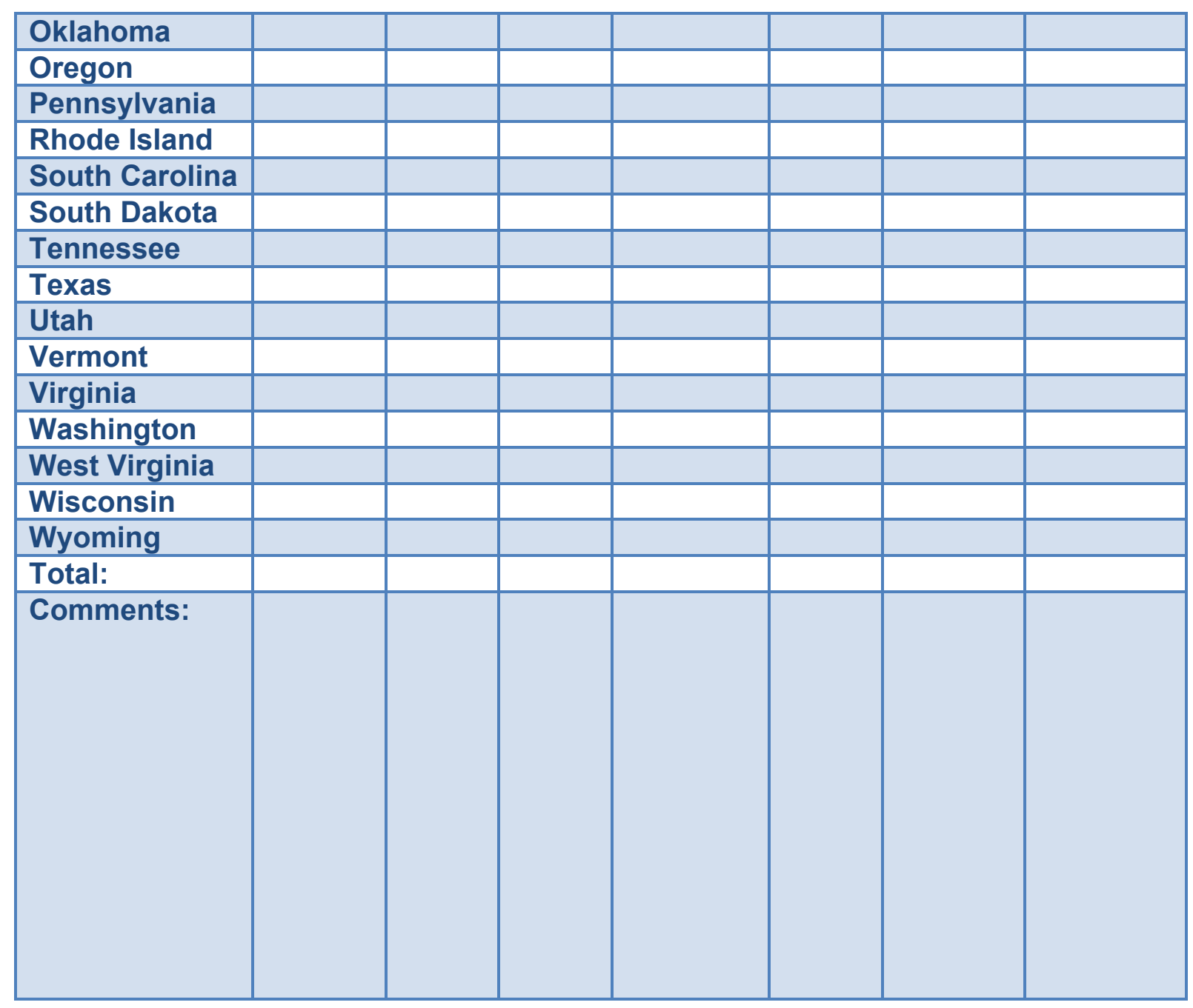




\section{APPENDIX B:}

\section{PROCESSES TO GAIN AND MAINTAIN LICENSURE}

\begin{tabular}{|c|c|c|c|c|c|c|}
\hline State & $\begin{array}{l}\text { Application: } \\
\text { Fee(s) }\end{array}$ & $\begin{array}{l}\text { Application: } \\
\text { Process } \\
\text { Time }\end{array}$ & $\begin{array}{l}\text { License } \\
\text { Maintenance: } \\
\text { Renewal } \\
\text { Cycle }\end{array}$ & $\begin{array}{l}\text { License } \\
\text { Maintenance: } \\
\text { Renewal } \\
\text { Fees }\end{array}$ & $\begin{array}{l}\text { License } \\
\text { Maintenance: } \\
\text { Process } \\
\text { Time }\end{array}$ & $\begin{array}{l}\text { "Limited } \\
\text { License" } \\
\text { Option }\end{array}$ \\
\hline \multicolumn{7}{|l|}{ Alabama } \\
\hline \multicolumn{7}{|l|}{ Alaska } \\
\hline \multicolumn{7}{|l|}{ Arizona } \\
\hline \multicolumn{7}{|l|}{ Arkansas } \\
\hline \multicolumn{7}{|l|}{ California } \\
\hline \multicolumn{7}{|l|}{ Colorado } \\
\hline \multicolumn{7}{|l|}{ Connecticut } \\
\hline \multicolumn{7}{|l|}{ Delaware } \\
\hline \multicolumn{7}{|l|}{$\begin{array}{l}\text { District of } \\
\text { Columbia }\end{array}$} \\
\hline \multicolumn{7}{|l|}{ Florida } \\
\hline \multicolumn{7}{|l|}{ Georgia } \\
\hline \multicolumn{7}{|l|}{ Hawaii } \\
\hline \multicolumn{7}{|l|}{ Idaho } \\
\hline \multicolumn{7}{|l|}{ Illinois } \\
\hline \multicolumn{7}{|l|}{ Indiana } \\
\hline \multicolumn{7}{|l|}{ lowa } \\
\hline \multicolumn{7}{|l|}{ Kansas } \\
\hline \multicolumn{7}{|l|}{ Kentucky } \\
\hline \multicolumn{7}{|l|}{ Louisiana } \\
\hline \multicolumn{7}{|l|}{ Maine } \\
\hline \multicolumn{7}{|l|}{ Maryland } \\
\hline \multicolumn{7}{|l|}{ Massachusetts } \\
\hline \multicolumn{7}{|l|}{ Michigan } \\
\hline \multicolumn{7}{|l|}{ Minnesota } \\
\hline \multicolumn{7}{|l|}{ Mississippi } \\
\hline \multicolumn{7}{|l|}{ Missouri } \\
\hline \multicolumn{7}{|l|}{ Montana } \\
\hline Nebraska & & & & & & \\
\hline Nevada & & & & & & \\
\hline $\begin{array}{l}\text { New } \\
\text { Hampshire }\end{array}$ & & & & & & \\
\hline New Jersey & & & & & & \\
\hline New Mexico & & & & & & \\
\hline New York & & & & & & \\
\hline North Carolina & & & & & & \\
\hline North Dakota & & & & & & \\
\hline Ohio & & & & & & \\
\hline
\end{tabular}




\begin{tabular}{|l|l|l|l|l|l|l|}
\hline Oklahoma & & & & & & \\
\hline Oregon & & & & & & \\
\hline Pennsylvania & & & & & & \\
\hline Rhode Island & & & & & & \\
\hline South Carolina & & & & & & \\
\hline South Dakota & & & & & & \\
\hline Tennessee & & & & & & \\
\hline Texas & & & & & & \\
\hline Utah & & & & & & \\
\hline Vermont & & & & & & \\
\hline Virginia & & & & & & \\
\hline Washington & & & & & \\
\hline West Virginia & & & & & & \\
\hline Wisconsin & & & & & & \\
\hline Wyoming & & & & & & \\
\hline Total: & & & & & & \\
\hline Comments: & & & & & & \\
\end{tabular}

